Hockenhull, D. J. D., Fantes, K. H., Herbert, M. \& Whitehead, B. (1954). J. gen. Microbiol. 10, 353-370.

\title{
Glucose utilization by Streptomyces griseus
}

\author{
By D. J. D. HOCKENHULL, K. H. FANTES, \\ MARY HERBERT AND BELINDA WHITEHEAD
}

Glaxo Laboratories Ltd., Sefton Park, Stoke Poges, Bucks.

SUMMARY: Glucose utilization by a strain of Streptomyces griseus was studied. Under highly aerobic conditions, glucose was converted mainly to structural material and $\mathrm{CO}_{2}$, but under restricted aeration, lactic acid was formed. Pyruvic acid was also formed during the stages of most rapid growth. The metabolism of glucose was dependent upon the presence of phosphate, and the optimal hydrogenion concentration for both glucose oxidation and the rate of disappearance of inorganic phosphate was about $\mathrm{pH} 7$. Phosphate esters, tentatively identified as glucose-1-phosphate and glucose-6-phosphate, were obtained in fluoride-inhibited systems. Glucose oxidation was depressed by $10^{-3} \mathrm{M}$-sodium iodoacetate and $10^{-2} \mathrm{M}$ sodium arsenite but was stimulated by $10^{-2} \mathrm{M}$-sodium arsenate $; 10^{-3} \mathrm{M}-2: 4$-dinitrophenol and $10^{-3} \mathrm{M}$-sodium azide had no effect. Streptomycin production was decreased by $3 \times 10^{-3} \mathrm{M}$-sodium arsenate but not by $10^{-2} \mathrm{M}$-sodium fluoride or $10^{-2} \mathrm{M}$ sodium iodoacetate. $S$. griseus metabolized members of the tricarboxylic acid cycle, although citrate and $\alpha$-ketoglutarate gave much lower values of $Q_{\mathrm{O}_{2}}$ at $\mathrm{pH} 7 \cdot 3$ than pyruvate, acetate, succinate, fumarate or malate. Ketoacids were produced in presence of arsenite from fumarate, malate, glucose, lactate, acetate, succinate, glutamate and citrate in descending order of yield. Except from fumarate, which yielded some material behaving like $\alpha$-ketoglutarate, the product was chiefly pyruvate.

Much of the literature on actinomycete metabolism, including the relationship between carbohydrate utilization, hydrogen-ion concentration and mould growth, was reviewed by Waksman (1950). Surveys of the availability of carbon from various carbohydrates were made for a wide range of organisms (Pridham \& Gottlieb, 1948), for Streptomyces coelicolor (Conn, 1943) and for S.griseus in connexion with streptomycin production (Dulaney \& Perlman, 1947; Dulaney, Hodges \& Perlman, 1947; Dulaney, 1949). The last-mentioned author divided the fermentation into two phases, crescence and senescence. In the former there was uptake of soluble nitrogen, carbon and phosphate into the mycelium, high oxygen demand and rapid utilization of glucose, but very little antibiotic production; in the latter phase, mycelial weight declined, phosphate and nitrogen were excreted into the medium, oxygen demand fell and streptomycin was produced. There was some formation of lactate early in fermentation, but this disappeared rapidly. Similar results were obtained by Woodruff $\&$ Ruger (1948). Typical fermentation diagrams were included in a later paper by Perlman \& Wagman (1952). The $\mathrm{pH}$ curve obtained by these authors for fermentations on glucose-containing media is typical not only of most aerobic $S$. griseus fermentations, but also for most Streptomyces spp. under similar conditions. The last-mentioned paper described the effect of replacing glucose by various lipid materials, and showed that growth and streptomycin pro- 
duction were maintained in a medium based upon soybean meal when all the glucose was replaced by soybean, cotton-seed or coconut oil. It was also shown that addition of extra phosphate to the glucose medium depressed streptomycin production and at the same time increased the rate of sugar disappearance. Addition of phosphate to an oil-containing medium depressed antibiotic production to a similar extent but caused no change in rate of lipid utilization. Without giving any figures, the authors state that phosphate increased the $Q_{\mathrm{O}_{2}}$ of the mould in presence of glucose or glycerol, but not in presence of lipids.

An attempt is made here to present a picture of the metabolism of glucose by a strain of $\boldsymbol{S}$. griseus and to relate the findings to pathways of phosphorolytic breakdown such as the Embden-Meyerhof scheme.

\section{METHODS}

Organism and cultural conditions. The organism, $S$. griseus albus mutant (Dulaney Z38), is described in the patent covering its production (Dulaney, 1951). The inoculum was grown for $48 \mathrm{hr}$. at $28^{\circ}$ with shaking on the following medium: glucose 10, dried enzymic digest of casein 10, sodium chloride 10, meat extract 6, g./l. distilled water. This was then used to inoculate $40 \mathrm{ml}$. of the following medium in $250 \mathrm{ml}$. conical flasks: glucose 25, soybean meal $\mathbf{4 0}$, sodium chloride $2 \cdot 5$, distillers' dried solubles 5 , g./l. distilled water $(\mathrm{pH}$ before autoclaving at $15 \mathrm{lb}$./sq.in. steam for $20 \mathrm{~min}$., 7·3-7·5). A defined medium, 'Lumb's medium' (Chesters \& Rolinson, 1951) was also used. This was based on glucose, glycine, sodium citrate and inorganic salts.

Preparation of mycelial suspensions. Mycelium from $48 \mathrm{hr}$. cultures (1 vol. medium) was washed 3 times with 1 vol. $0.01 \mathrm{M}$-potassium phosphate $\mathrm{pH} 7 \cdot 0$, and re-suspended in 1 vol. of similar buffer. After incubating with shaking for

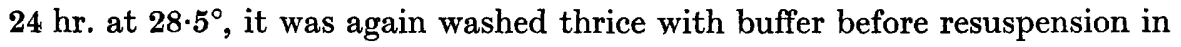
similar buffer for experimentation. The method of washing and starving is similar to that described for Penicillium chrysogenum (Hockenhull, Walker, Wilkin \& Winder, 1952).

Although growth was sometimes abnormally rapid, maximal mycelial weight was usually achieved on Lumb's medium after 2-3 days. Maximal respiratory activity was manifest at 1 day.

The $Q_{\mathrm{o}_{\mathrm{a}}}$ value for whole broth was highest at $24 \mathrm{hr}$., fell slowly to $48 \mathrm{hr}$. after which it declined rapidly to $50 \%$ in $\mathbf{7 2} \mathrm{hr}$., while that for washed mycelium with respect to glucose had fallen only about $15 \%$ in the same time (Table 1; see Gottlieb \& Anderson, 1948).

Manometric measurements. Oxygen uptake was measured using Warburg manometers with single sidebulb cups fitted with centre-wells. The temperature was $28.5^{\circ}$ and the gas phase was air. The results obtained are expressed as $Q_{\mathrm{O}_{2}}=\mu \mathrm{l} . \mathrm{O}_{2}$ consumed $/ \mathrm{mg}$. dry-wt. mycelium $/ \mathrm{hr}$. When the effect of various treatments, e.g. the use of inhibitors, was investigated the assumption was made that there was no interaction between the action of substrate and inhibitor upon the endogenous respiration. The respiration due to substrate in 
presence of inhibitor was corrected by subtraction of the endogenous respiration in presence of inhibitor. Attention is drawn to the arbitrary nature of this proceeding.

\section{Table 1. Respiratory activity of $\mathrm{S}$. griseus at different ages}

$S$. griseus grown in defined medium ( $40 \mathrm{ml}$. medium $/ 250 \mathrm{ml}$. flask) with shaking at $28 \cdot 5^{\circ}$. Sets of three replicate flasks harvested daily. Washing and starving carried out by the standard procedure with $3 \times 1$ vol. $0.01 \mathrm{M}$-phosphate $\mathrm{pH} \mathrm{7.0}$. Warburg manometers contained: in main compartment, $2 \mathrm{ml}$. mycelial suspension; in side bulb, $0.2 \mathrm{ml} .0 .01 \mathrm{M}$-phosphate buffer, with or without $0 \cdot 1 \mathrm{M}$-glucose; in centre well, $0.1 \mathrm{ml} .10 \mathrm{~N}-\mathrm{KOH}$ on filter-paper. Measurements taken at $28 \cdot 5^{\circ}$ over 30 min.

\begin{tabular}{|c|c|c|c|c|c|c|c|c|c|c|}
\hline \multirow{2}{*}{\multicolumn{2}{|c|}{$\begin{array}{c}\text { Mycelial } \\
\text { wt. } \\
\text { Day (mg./ml.) }\end{array}$}} & \multirow[b]{2}{*}{$\mathrm{pH}$} & \multirow[b]{2}{*}{$\begin{array}{c}\text { Strepto- } \\
\text { mycin } \\
\text { (mg./l.) }\end{array}$} & \multirow[b]{2}{*}{$\begin{array}{c}\text { Whole } \\
\text { broth } \\
Q_{\mathrm{O}_{2}}\end{array}$} & \multicolumn{3}{|c|}{ Washed mycelium, $Q_{\mathrm{O}_{2}}$} & \multicolumn{3}{|c|}{$\begin{array}{l}\text { Washed starved } \\
\text { mycelium, } \mathbf{Q}_{\mathrm{O}_{2}}\end{array}$} \\
\hline & & & & & $\underset{\text { (total) }}{\mathrm{A}}$ & $\begin{array}{c}B \\
\text { (endo- } \\
\text { genous) }\end{array}$ & $\begin{array}{l}\text { A-B } \\
\text { (glu- } \\
\text { cose) }\end{array}$ & $\underset{\text { (total) }}{\mathbf{C}}$ & $\begin{array}{c}\mathrm{D} \\
\text { (endo- } \\
\text { genous) }\end{array}$ & $\begin{array}{l}\text { C-D } \\
\text { (glu- } \\
\text { cose) }\end{array}$ \\
\hline 0 & 0.017 & $6 \cdot 24$ & 0 & - & - & - & - & - & - & - \\
\hline 1 & 0.75 & 6.94 & 0 & $\begin{array}{l}-\overline{48 \cdot 0} \\
48 \cdot 8\end{array}$ & $\begin{array}{l}45 \cdot 6 \\
48 \cdot 8 \\
50 \cdot 8\end{array}$ & $\left.\begin{array}{l}18 \cdot 6 \\
19 \cdot 2 \\
19 \cdot 7\end{array}\right\}$ & $29 \cdot 2$ & - & - & - \\
\hline 2 & $3 \cdot 43$ & $7 \cdot 78$ & 0 & $\begin{array}{l}43 \cdot 7 \\
43 \cdot 1 \\
42 \cdot 7\end{array}$ & $\begin{array}{l}43 \cdot 6 \\
42 \cdot 9 \\
42 \cdot 8\end{array}$ & $\left.\begin{array}{l}17 \cdot 5 \\
18 \cdot 0 \\
17 \cdot 6\end{array}\right\}$ & $26 \cdot 4$ & $\left\{\begin{array}{l}28 \cdot 4 \\
28 \cdot 8 \\
27 \cdot 8\end{array}\right.$ & $\left.\begin{array}{r}10 \cdot 1 \\
9 \cdot 9\end{array}\right\}$ & $18 \cdot 3$ \\
\hline 3 & $11 \cdot 6$ & $8 \cdot 10$ & 215 & $\begin{array}{l}23 \cdot 9 \\
24 \cdot 0\end{array}$ & $\begin{array}{l}40 \cdot 0 \\
41 \cdot 6\end{array}$ & $\left.\begin{array}{l}16.2 \\
15.9\end{array}\right\}$ & 24.75 & $\begin{array}{l}16.4 \\
16.5\end{array}$ & $\left.\begin{array}{l}6 \cdot 75 \\
6 \cdot 65\end{array}\right\}$ & $9 \cdot 8$ \\
\hline 4 & $10 \cdot 05$ & $8 \cdot 50$ & 245 & $\begin{array}{l}10 \cdot 1 \\
10 \cdot 1\end{array}$ & $\begin{array}{l}14 \cdot 8 \\
15 \cdot 0\end{array}$ & $\left.\begin{array}{l}8 \cdot 3 \\
8 \cdot 3\end{array}\right\}$ & $6 \cdot 6$ & $\left\{\begin{array}{l}9 \cdot 6 \\
9 \cdot 8\end{array}\right.$ & $\left.\begin{array}{l}3 \cdot 5 \\
3.7\end{array}\right\}$ & $6 \cdot 1$ \\
\hline 5 & $10 \cdot 25$ & 8.96 & 220 & $\begin{array}{l}5 \cdot 05 \\
5 \cdot 0\end{array}$ & $\begin{array}{l}9 \cdot 85 \\
9 \cdot 45\end{array}$ & $\left.\begin{array}{l}4 \cdot 15 \\
4 \cdot 15\end{array}\right\}$ & $5 \cdot 5$ & $\left\{\begin{array}{l}8.2 \\
8 \cdot 4\end{array}\right.$ & $\left.\begin{array}{l}2 \cdot 3 \\
2 \cdot 6\end{array}\right\}$ & 5.95 \\
\hline 6 & $10 \cdot 35$ & 8.98 & 240 & $\begin{array}{l}2 \cdot 8 \\
2 \cdot 6\end{array}$ & $\begin{array}{l}8 \cdot 3 \\
8 \cdot 4\end{array}$ & $\left.\begin{array}{l}3 \cdot 2 \\
3 \cdot 1\end{array}\right\}$ & $5 \cdot 15$ & - & - & - \\
\hline
\end{tabular}

\section{Analytical procedures}

Carbohydrates. Total reducing sugar was determined by the method of Somogyi (1937). Reducing sugars after hydrolysis (expressed as glucose) were determined by the same method after heating in $0.8 \mathrm{~N}-\mathrm{HCl}$ at $120^{\circ}$ for $30 \mathrm{~min}$. and neutralizing with $\mathrm{NaOH}$. Qualitative examination of carbohydrate materials was carried out chromatographically by descending flow on Whatman No. 4 paper. The solvents most frequently used were $n$-butanol/pyridine/water mixtures, $3 / 2 / 1 \cdot 5$ or $4 / 1 / 1$ by volume (Jeanes, Wise \& Dimler, 1951). Carbohydrates were located by spraying with acid naphthoresorcinol (Bryson \& Mitchell, 1951) or methanolic borate-phenol red (Hockenhull, 1953). Aminosugars were located by a spray (Partridge, 1949) based on the reaction of Elson \& Morgan (1933).

Lactate was determined by the method of Gordon \& Quastel (1939) which is claimed not to suffer interference from pyruvate. Carboxylic acids were separated by paper chromatography (Lugg \& Overell, 1947; Stark, Goodban \& Owens, 1951), as also were amino acids using the solvent systems of Partridge (1948). Keto-acids were estimated by the method of Friedemann \& Haugen 
(1943). They were separated by paper chromatography of the $2: 4$-dinitrophenylhydrazones (Cavallini, Frontali \& Toschi, 1949) or of the nitroquinoxalinols formed by condensation of $\alpha$-ketoacids with $1: 2$-diamino-4-nitrobenzene (Hockenhull \& Floodgate, 1952; Hockenhull, Hunter \& Herbert, 1953). Larger quantities of these derivatives were separated by chromatography on alumina columns (Datta, Harris \& Rees, 1950; Hockenhull, Herbert, Walker, Wilkin \& Winder, 1954; Hockenhull \& Floodgate, 1952).

Streptomycin was determined as maltol (Boxer, Jelinek \& Leghorn, 1947).

Phosphate was determined by the method of Fiske \& Subbarow (1925). Sugar phosphates were fractionated by the method of Vercellone \& Neuberg (1935). Fructose was estimated by the method of Roe (1934). Phosphate esters were separated chromatographically by ascending flow on Whatman no. 4 paper using the solvent systems methanol/formic acid/water (80/15/5, $\mathrm{v} / \mathrm{v}$ ) and methanol/ammonia (sp.gr. 0.88)/water (60/10/30, v/v) (Bandurski \& Axelrod, 1951).

\section{RESULTS}

\section{Changes in the carbohydrate content of Streptomyces griseus cultures}

Changes in soybean medium. Soybean medium contains glucose as the principal carbohydrate with certain carbohydrates from the soybean mealsucrose, raffinose, stachyose (Street \& Bailey, 1915; Sato, 1921). After sterilization some material resembling fructose is present. Cultures were harvested in triplicate at regular intervals and the residual carbohydrate determined (Table 2).

The initial non-reducing sugar, averaging $3.6 \mathrm{mg} . / \mathrm{ml}$. as glucose, was accountable for by the non-utilizable sugars of soybean meal, sucrose, raffinose and stachyose (Pridham \& Gottlieb, 1948). A rise after 2 days to about $6 \mathrm{mg} . / \mathrm{ml}$. indicated a synthesis of some other hydrolysable carbohydrate material which was of a transient nature, the total falling to about $4.0 \mathrm{mg} . / \mathrm{ml}$. at 3 days. In the later stages of growth, the hydrolysable carbohydrate rose to about $8 \mathrm{mg}$./ml., implying a considerable synthesis of sugar polymers. Paper chromatographic separation of the sugars from a similar fermentation revealed no identifiable carbohydrates other than sucrose, raffinose, stachyose, glucose and a material similar to fructose which was possibly derived from glucose by isomerization during sterilization. The three non-utilizable sugars were also separated by means of charcoal columns (Whistler \& Durso, 1950), but no new substances synthesized during growth could be detected.

Changes in Lumb's medium. Table 3 shows the amount of reducing sugar in filtrates from cultures of $\boldsymbol{S}$. griseus growing on Lumb's medium. Very little more reducing sugar appeared after acid hydrolysis, indicating little polymerization of sugars. Although the medium contained glucose as sole carbohydrate before autoclaving, a number of new substances reacting like carbohydrate appeared after heat treatment. A material which behaved chromatographically like, and presumably was, fructose (possibly formed by a Lobry de Bruyn isomerization), disappeared at roughly the same rate as glucose. A number of spots which became red or purple on treatment with 
naphthoresorcinol were also formed. The substances corresponding to these were not utilized, and probably represented only a small proportion of the

Table 2. Sugar content of soybean medium during growth of $\mathrm{S}$. griseus

Cultures on soybean medium grown as described by Dulaney (1951) at $28.5^{\circ}$ with shaking. Flasks removed daily in triplicate for determinations.

\begin{tabular}{|c|c|c|c|}
\hline Day & $\begin{array}{l}\text { Reducing sugar } \\
\text { (mg./ml.) }\end{array}$ & $\begin{array}{l}\text { Total sugar } \\
\text { after acid } \\
\text { hydrolysis } \\
\text { (mg./ml.) }\end{array}$ & $\begin{array}{c}\text { Non-reducing } \\
\text { sugar } \\
\text { (mg./ml.) }\end{array}$ \\
\hline 0 & $\begin{array}{l}26 \cdot 0 \\
25 \cdot 7 \\
25 \cdot 9\end{array}$ & $\begin{array}{l}\mathbf{2 9 \cdot 9} \\
29 \cdot 7 \\
\mathbf{2 8} \cdot 9\end{array}$ & $\begin{array}{l}3 \cdot 90 \\
3 \cdot 95 \\
3 \cdot 00\end{array}$ \\
\hline 1 & $\begin{array}{l}25 \cdot 3 \\
24 \cdot 8 \\
25 \cdot 3\end{array}$ & $\begin{array}{l}29 \cdot 7 \\
29 \cdot 5 \\
29 \cdot 0\end{array}$ & $\begin{array}{l}4 \cdot 40 \\
4 \cdot 70 \\
3 \cdot 75\end{array}$ \\
\hline 2 & $\begin{array}{l}14 \cdot 4 \\
17 \cdot 0 \\
14 \cdot 7\end{array}$ & $\begin{array}{l}21 \cdot 7 \\
22 \cdot 2 \\
20 \cdot 5\end{array}$ & $\begin{array}{l}7 \cdot 25 \\
5 \cdot 15 \\
5 \cdot 80\end{array}$ \\
\hline 3 & $\begin{array}{l}10 \cdot 2 \\
10 \cdot 9 \\
11 \cdot 3\end{array}$ & $\begin{array}{l}14.0 \\
14 \cdot 5 \\
14 \cdot 8\end{array}$ & $\begin{array}{l}3 \cdot 85 \\
4 \cdot 60 \\
3 \cdot 45\end{array}$ \\
\hline 4 & $\begin{array}{l}7 \cdot 00 \\
7 \cdot 10 \\
7 \cdot 87\end{array}$ & $\begin{array}{l}12 \cdot 65 \\
12 \cdot 65 \\
12 \cdot 72\end{array}$ & $\begin{array}{l}5 \cdot 65 \\
5 \cdot 55 \\
5 \cdot 85\end{array}$ \\
\hline 5 & $\begin{array}{l}2 \cdot 70 \\
2 \cdot 40 \\
2 \cdot 25\end{array}$ & $\begin{array}{r}9 \cdot 95 \\
10 \cdot 00 \\
10 \cdot 10\end{array}$ & $\begin{array}{l}7 \cdot 25 \\
7 \cdot 60 \\
7 \cdot 85\end{array}$ \\
\hline 6 & $\begin{array}{l}1.50 \\
1.50 \\
0.67\end{array}$ & $\begin{array}{r}10 \cdot 00 \\
8 \cdot 50 \\
8 \cdot 50\end{array}$ & $\begin{array}{l}8 \cdot 50 \\
7 \cdot 00 \\
7 \cdot 83\end{array}$ \\
\hline 7 & $\begin{array}{l}1 \cdot 25 \\
1 \cdot 25 \\
1 \cdot 25\end{array}$ & $\begin{array}{l}9 \cdot 50 \\
8 \cdot 75 \\
9 \cdot 50\end{array}$ & $\begin{array}{l}8 \cdot 25 \\
7 \cdot 50 \\
8 \cdot 25\end{array}$ \\
\hline 8 & $\begin{array}{l}1 \cdot 25 \\
1 \cdot 25 \\
1 \cdot 25\end{array}$ & $\begin{array}{l}9 \cdot 50 \\
8 \cdot 40 \\
8 \cdot 35\end{array}$ & $\begin{array}{l}8 \cdot 25 \\
7 \cdot 15 \\
7 \cdot 10\end{array}$ \\
\hline
\end{tabular}

Table 3. Changes in carbohydrate content of Lumb's medium during growth of $\mathrm{S}$. griseus

Cultures grown at $28.5^{\circ}$ with shaking. Flasks removed in triplicate and pooled for analysis.

\begin{tabular}{|c|c|c|c|c|c|c|c|c|}
\hline \multicolumn{9}{|c|}{ Day } \\
\hline 0 & 1 & 2 & 3 & 4 & 5 & 6 & 7 & 8 \\
\hline \multicolumn{9}{|c|}{ Reducing sugar (mg./ml.) } \\
\hline
\end{tabular}

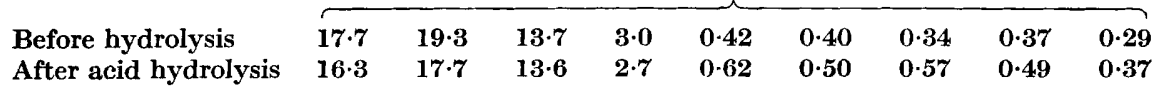

total carbohydrate. Autoclaving the medium constituents in pairs at similar concentrations to those in Lumb's medium led to formation of substances which reacted with acid naphthoresorcinol from $(a)$ glycine heated alone, and 
(b) by interaction between glucose or citrate and the trace minerals (Table 4). The spots from glycine may have been due to its reaction with cellulose on drying or treating the paper with acid naphthoresorcinol.

Table 4. Chromatographic behaviour of autoclaved mixtures of components of Lumb's medium at concentration and $\mathrm{pH}$ value of medium

$R_{\mathrm{G}}$ is defined as the ratio of the distance moved by the spot to the distance moved by glucose.

\begin{tabular}{ll}
\multicolumn{1}{c}{$\begin{array}{c}\text { Medium } \\
\text { component }\end{array}$} & \multicolumn{1}{c}{$\begin{array}{c}\text { Colour or nature } \\
\text { of spot }\end{array}$} \\
Glucose (A) & Glucose and fructose spots \\
Glycine (B) & Reddish pink \\
Na-citrate (C) & Nil \\
Inorganic salts (D) & Nil \\
A+B & Glucose, fructose and \\
& glycine spots \\
A+C & Glucose and fructose spots \\
Awo purple spots, one & pinkish spot, glucose \\
& and fructose \\
B+D & As B \\
C+D & Pink spot \\
&
\end{tabular}

Distance moved (cm.) in $16 \mathrm{hr}$. (butanol/pyridine/water $(3: 2: 1 \cdot 5)$

Approximate

Glucose 22, fructose 27 1

$\boldsymbol{R}_{\mathrm{G}}$

$$
\overline{0.05}
$$

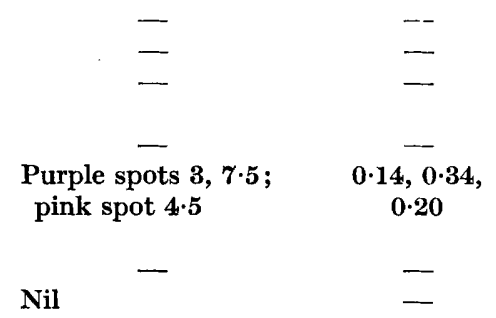

Further experiments, not yet satisfactorily concluded, were carried out to determine the relative amounts of various carbohydrate fractions in the mycelium. The method used, that of Trevelyan, Forrest \& Harrison (1952), was subject to considerable sampling error, different sugars varied in extent of reaction, and the fractionation procedures appeared to affect the amount of colour given with the reagent. It was noteworthy, however, that there was present no carbohydrate insoluble in $30 \% \mathrm{KOH}$. A typical set of results on $120 \mathrm{ml}$. of a 4-day culture on Lumb's medium gave: total mycelial dry weight $465 \mathrm{mg}$; t total anthrone value $47 \mathrm{mg}$. glucose equivalent, fraction soluble in $10 \%$ trichloroacetic acid $28 \mathrm{mg}$. glucose equivalent, residue after $30 \% \mathrm{KOH}$ extraction, nil; $59 \mathrm{mg}$. total mycelial nitrogen (which would correspond, ignoring amino-sugars and other non-protein nitrogen, to about $360 \mathrm{mg}$. protein).

\section{The mechanism of glucose utilization}

Effect of phosphate level upon $\mathbf{Q}_{\mathrm{O}_{2}}$ (glucose). Preliminary work with mycelia washed and starved in water instead of phosphate buffer, indicated that glucose, fructose, mannose, glucose-1-phosphate and hexose diphosphate gave closely similar $Q_{\mathrm{O}_{2}}$ values, whereas starch and gluconate were very much less easily oxidized (Table 5). The effect of phosphate was unusually small, presumably because the cells were still replete with inorganic phosphate. The above experiment was exceptional; in all other experiments in which starving and washing were carried out in water, it was found that inorganic phosphate (pH 7-3) profoundly stimulated the respiration in presence of glucose (Table 6). Orthophosphate could not be replaced by either glucose-1-phosphate or hexose diphosphate. 
Table 5. Oxygen uptake of $\mathbf{S}$. griseus in presence of substrates related to the Embden Meyerhof scheme

Warburg manometers contained: main compartment, $9.8 \mathrm{mg}$. dry-wt. mycelium in $2 \mathrm{ml}$. water; side bulb, $0.2 \mathrm{ml} .0 .01 \mathrm{M}$ substrate; centre well, $0.1 \mathrm{ml}$. $10 \mathrm{~N}-\mathrm{KOH}$ with filter-paper. Temp. 28.5 ${ }^{\circ}$ Gas phase, air. The $\mathrm{pH}$ of substrates and suspensions were adjusted to $\mathrm{pH} \mathbf{7 \cdot 2}$.

Substrate

Endogenous

Glucose

Fructose

Mannose

Glucose-1-phosphate

Hexose diphosphate

Starch

Sodium gluconate
$Q_{\mathrm{O}_{2}}$ in presence of

0.01 M-phosphate

pH $7 \cdot 2$ (corrected

for endogenous)

$20 \cdot 2$

$18 \cdot 6$

16.4

$18 \cdot 2$

$\overline{21 \cdot 7}$

$\mathbf{3 \cdot 9}$

Table 6. The effect of orthophosphate and sugar phosphates upon oxygen uptake by $\mathrm{S}$. griseus in presence of glucose

Warburg manometers contained: main compartment, about $12 \mathrm{mg}$. dry-wt. starved mycelium in $2 \mathrm{ml}$. water, $\mathrm{pH} 7.0$; side bulb, $0.1 \mathrm{M}$ substrate in $0.2 \mathrm{ml}$; centre reell, $10 \mathrm{~N}-\mathrm{KOH}$ with filter-paper. Temp. $\mathbf{2 8} \cdot 5^{\circ}$.

\begin{tabular}{|c|c|c|c|c|c|}
\hline Glucose & $\begin{array}{c}\text { Ortho- } \\
\text { phosphate }\end{array}$ & $\begin{array}{c}\text { Hexose } \\
\text { diphosphate }\end{array}$ & $\begin{array}{l}\text { Glucose-1- } \\
\text { phosphate }\end{array}$ & \multirow{3}{*}{$\left.\begin{array}{c}Q_{\mathrm{O}_{2}} \\
11 \cdot 5 \\
11 \cdot 5\end{array}\right\}$} & \multirow{3}{*}{$\begin{array}{c}Q_{\mathrm{O}_{2}} \\
\text { (mean increase } \\
\text { over endogenous) } \\
-\end{array}$} \\
\hline \multicolumn{4}{|c|}{ Final concentration in mixture } & & \\
\hline 0 & 0 & 0 & 0 & & \\
\hline $0.01 \mathrm{M}$ & 0 & 0 & 0 & $\left.\begin{array}{l}28 \cdot 7 \\
28 \cdot 6\end{array}\right\}$ & $17 \cdot 2$ \\
\hline $\mathbf{0}$ & $0.01 \mathrm{M}$ & 0 & $\mathbf{0}$ & $\left.\begin{array}{l}17 \cdot 0 \\
17 \cdot 2\end{array}\right\}$ & $5 \cdot 6$ \\
\hline $0.01 M$ & $0.01 \mathrm{M}$ & $\mathbf{0}$ & o & $\left.\begin{array}{l}52 \cdot 1 \\
52 \cdot 3\end{array}\right\}$ & $40 \cdot 7$ \\
\hline $0.01 \mathrm{M}$ & o & $0.01 \mathrm{M}$ & 0 & $\left.\begin{array}{l}26 \cdot 7 \\
28 \cdot 2\end{array}\right\}$ & $15 \cdot 8$ \\
\hline $0.01 \mathrm{M}$ & $\mathbf{0}$ & $\mathbf{0}$ & $0.01 \mathrm{M}$ & $\left.\begin{array}{l}27 \cdot 9 \\
28 \cdot 2\end{array}\right\}$ & $16 \cdot 6$ \\
\hline
\end{tabular}

Effect of phosphate upon glucose disappearance. Suspensions of $\boldsymbol{S}$. griseus washed and starved in water were incubated at $28 \cdot 5^{\circ}$ with shaking, in presence of glucose, and various concentrations of phosphate buffer $\mathrm{pH} 7 \cdot 3$. Glucose utilization increased with rising phosphate concentration (Table 7), a result fully consistent with the respirometric findings. It should be noted, however, that the $\mathrm{pH}$ optima for both glucose and phosphate utilization are extremely sharp. Although the initial $\mathrm{pH}$ was the same in all treatments $(\mathrm{pH} 7 \cdot 3)$ the final $\mathrm{pH}$ may have risen to values giving faster rates of utilization where more phosphate was present. The effects were, however, somewhat larger than would have been expected if $\mathrm{pH}$ change was the whole reason. 
Isolation of phosphorylated intermediates. Attempts to trap triosephosphates as the phenylhydrazine derivative of methylglyoxal, on similar lines to the work of Scevola \& Valcurone (1952), proved unsuccessful, although traces of pyruvate were noted. Consequently an attempt was made to obtain phosphate esters by the incubation of mycelium with glucose and phosphate in presence of fluoride. The technique used was similar to that of Neuberg \& Kobel (1933).

\section{Table 7. Effect of phosphate concentration on glucose utilization}

$232 \mathrm{mg}$. dry-wt. mycelium in $20 \mathrm{ml}$. of glucose solution $1.64 \mathrm{mg} . / \mathrm{ml}$., with varying levels of phosphate, shaken in $250 \mathrm{ml}$. conical flasks for $4 \mathrm{hr}$. at $28 \cdot 5^{\circ}$.

$\begin{array}{cc}\begin{array}{c}\text { Added K-phosphate } \\ \mathrm{pH} 7 \cdot 3\end{array} & \begin{array}{c}\text { Glucose utilized } \\ (\mathrm{mg} . / \mathrm{ml} .)\end{array} \\ (\mathrm{M}) & 0 \cdot 62 \\ 0 & 0.92 \\ 0.001 & 1 \cdot 24 \\ 0.002 & 1 \cdot 64 \\ 0.01 & 1.58 \\ 0.02 & 1 \cdot 50 \\ 0.10 & \end{array}$

A qualitative experiment was carried out with mycelium from $6 \mathrm{l}$. of $24 \mathrm{hr}$. cultures of $\boldsymbol{S}$. griseus in meat medium (about $50 \mathrm{~g}$. dry matter). After washing, this was re-suspended in a mixture of $100 \mathrm{ml} .0 .1 \mathrm{M}$-potassium phosphate pH 7.0, $100 \mathrm{ml} .20 \%$ (w/v) glucose, $100 \mathrm{ml} .0 \cdot 3 \mathrm{M}$-sodium fluoride, $20 \mathrm{ml} .10 \%$ $(\mathrm{v} / \mathrm{v})$ acetaldehyde and water to a total volume of $1 \mathrm{l}$., the $\mathrm{pH}$ value being

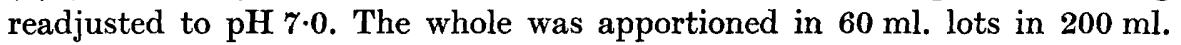
conical flasks and agitated aerobically at $28 \cdot 5^{\circ}$ for $18 \mathrm{hr}$. After incubation it was worked up by the technique of Neuberg \& Kobel (1933). The yield of water-soluble barium phosphate esters was low (69 $\mathrm{mg}$. phosphorus), and consisted of acid hydrolysable phosphate (glucose 1-phosphate fraction) $42 \%$, alkali hydrolysable $30 \%$, hexose-diphosphate $0 \%$ and glucose 6 -phosphate (by difference) $28 \%$. The presence of glucose-1-phosphate and glucose-6phosphate was confirmed by paper chromatography (Table 8), but no other

\section{Table 8. Chromatographic separation of phosphate esters}

Water-soluble barium salts, obtained by fluoride-inhibited metabolism of glucose, examined by the technique of Bandurski \& Axelrod (1951). The solvent fronts in both systems moved about $20 \mathrm{~cm}$. in $2 \mathrm{hr}$.

Standard substances Glucose-1-phosphate Glucose-6-phosphate Hexose diphosphate Orthophosphate

Ba esters soluble in water

\begin{tabular}{|c|c|}
\hline \multicolumn{2}{|c|}{$\boldsymbol{R}_{\mathrm{F}}$} \\
\hline $\begin{array}{l}\text { Methanol/formic } \\
\text { acid/water } \\
(80: 15: 5)\end{array}$ & $\begin{array}{c}\text { Methanol } / 0 \cdot 880 \mathrm{sp} . \mathrm{gr} . \\
\text { ammonia/water } \\
(60: 10: 30)\end{array}$ \\
\hline $0 \cdot 16$ & $0 \cdot 62$ \\
\hline $0 \cdot 39$ & 0.36 \\
\hline 0.42 & 0.25 \\
\hline 0.65 & 0.28 \\
\hline $0 \cdot 16$ & 0.64 \\
\hline $0 \cdot 36$ & 0.37 \\
\hline $0 \cdot 63$ & $0 \cdot 27$ \\
\hline
\end{tabular}


esters were identified. No hexose-diphosphate could be detected in the water insoluble phosphate fraction. No esters were detectable in samples taken at the commencement of incubation.

A smaller experiment was carried out on the same lines as above, using mycelial suspensions from cultures on Lumb's medium $(\mathbf{1} \cdot 6 \mathrm{~g}$. dry wt.) in volumes of $50 \mathrm{ml}$. Fluoride was omitted from one flask. The water soluble barium salts, which gave a similar pattern on chromatography, amounted to $0 \cdot 281 \mathrm{~g}$. with sodium fluoride and $0 \cdot 132 \mathrm{~g}$. without sodium fluoride.

Dependence of glucose oxidation on hydrogen-ion concentration. Washed starved mycelial suspensions were incubated with $0.01 \mathrm{M}$-glucose in presence of $0.1 \mathrm{M}$-potassium phosphate buffer at various $\mathrm{pH}$ values. The suspension was

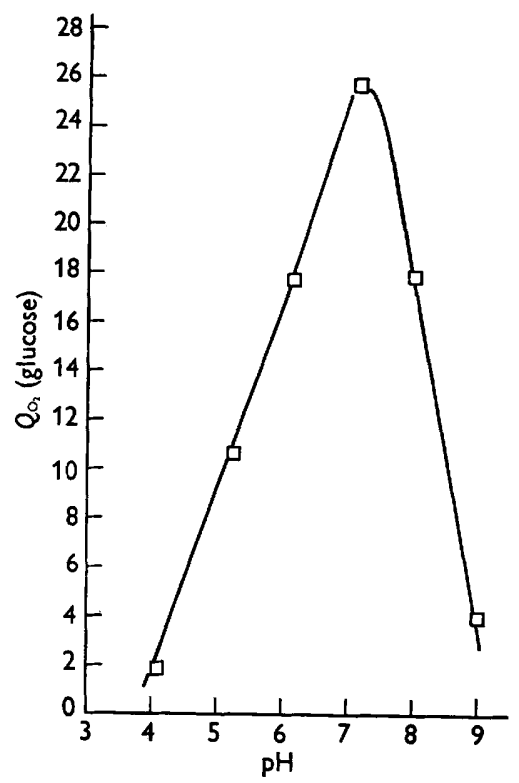

Fig. 1. Effect of hydrogen-ion concentration upon oxygen uptake in presence of glucose. Warburg manometers contained: main compartment, $5 \cdot 6 \mathrm{mg}$. dry-wt. starved mycelium in $2 \mathrm{ml} .0 \cdot 1 \mathrm{M}-\mathrm{K}$ phosphate buffer at appropriate $\mathrm{pH}$; side bulb, $0 \cdot 2 \mathrm{ml} .0 \cdot 1 \mathrm{M}$-glucose in $0 \cdot 1 \mathrm{M}-\mathrm{K}$ phosphate at appropriate $\mathrm{pH}$; centre well, $0 \cdot 1 \mathrm{ml} .10 \mathrm{~N}-\mathrm{KOH}$ with filter-paper. Temp. $28 \cdot 5^{\circ}$. Gas phase, air.

made in similar buffer, which was adjusted to the correct $\mathrm{pH}$ with $\mathrm{N}-\mathrm{HCl}$ or $\mathrm{N}-\mathrm{KOH}$. Fig. 1 indicates the dependence of respiration on $\mathrm{pH}$ and shows that the maximum lies near $\mathrm{pH} \mathbf{7 \cdot 0}$.

Effect of hydrogen-ion concentration upon phosphate utilization. Mycelium from $48 \mathrm{hr}$. cultures of $S$. griseus was spun down and washed 4 times with distilled water and once with $0.05 \mathrm{M}$-barbiturate buffer, $\mathrm{pH} 7 \cdot 02 . \mathrm{KH}_{2} \mathrm{PO}_{4}$ $(0.080 \mathrm{~g}$.) was dissolved in $20 \mathrm{ml} .0 .05 \mathrm{M}$-barbiturate buffer and added to the mycelium resuspended in $200 \mathrm{ml}$. of buffer containing $0.01 \mathrm{M}$-glucose. The $\mathrm{pH}$ value of $20 \mathrm{ml}$. portions in $250 \mathrm{ml}$. conical flasks was adjusted with conc. $\mathrm{HCl}$ or $10 \mathrm{~N}-\mathrm{NaOH}$, to avoid dilution. Flasks were shaken aerobically at $\mathbf{2 8 . 5}{ }^{\circ}$ for $4 \mathrm{hr}$. after taking $2 \mathrm{ml}$. from each for phosphate determination, which 
was repeated at the end of the $4 \mathrm{hr}$. Fig. 2 shows the relationship between mean $\mathrm{pH}$ over the $4 \mathrm{hr}$. of the experiment and ortho-phosphate disappearing. Maximal phosphate disappearance took place between $\mathrm{pH} \mathbf{7 \cdot 0}$ and $\mathbf{7 \cdot 5}$, this maximum corresponding with that for glucose utilization as measured by the $Q_{\mathrm{O}_{2}}$ (glucose) value. Care is necessary in interpreting this experiment as there was a considerable shift in pH. This has been compensated for in Fig. 3 by using the mean value. In the experiment giving a mean of $9 \cdot 00$, the $\mathrm{pH}$ moved from 9.52 to $8 \cdot 48$, in that giving a mean of $6 \cdot 28$ from $\mathrm{pH} 5 \cdot 48$ to $7 \cdot 08$, in the experiment showing an initial value of $5 \cdot 12, \mathrm{pH}$ did not change much

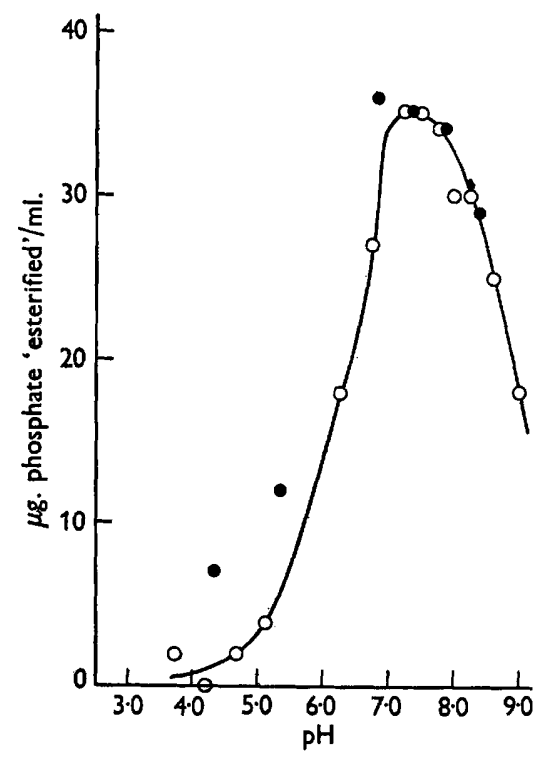

Fig. 2. Effect of hydrogen-ion concentration upon the esterification of inorganic phosphate. $250 \mathrm{ml}$. conical flasks containing $82 \mu \mathrm{g}$. orthophosphate $\mathrm{P} / \mathrm{ml}$. in $20 \mathrm{ml}$. $0.05 \mathrm{~m}$-barbiturate buffer at various $\mathrm{pH}$ values with $0.01 \mathrm{~m}$-glucose and $13.1 \mathrm{mg}$. dry weight mycelium $/ \mathrm{ml}$. Shaken for $4 \mathrm{hr}$. at $28 \cdot 5^{\circ}$. The two sets of points represent parallel experiments with similarly prepared mycelium.

$(5 \cdot 02-5 \cdot 25)$, and at this value phosphorylation, very significantly, fell almost to zero. The initial value at which there was no change was 8.02. Another similar set of results is embodied in Fig. 2.

\section{Anaerobic metabolism}

Production of lactic acid in Lumb's medium under conditions of restricted aeration. Cultures of $\boldsymbol{S}$. griseus were grown on Lumb's medium with shaking. After $24 \mathrm{hr}$. aerobic growth, during which time a considerable mycelial weight had been produced, half of the flasks were fitted with tight rubber caps to exclude air. At regular intervals, flasks were removed in triplicate, lactic acid, glucose and dry matter were determined, and their mean values were plotted against time of incubation (Fig. $3 a, b$ ). There was very little change in metabolism during the early stages, when presumably sufficient oxygen for respira- 
tion remained in the capped flask. However, the mycelial weight increased much more slowly under restricted aeration, so that the rate of glucose utilization/mg. of dry matter was higher under anaerobic conditions. Although there was a moderate quantity of lactic acid in both series by the second day, this increased to the high value of $5 \cdot 6 \mathrm{mg}$. $/ \mathrm{ml}$. by the third day in the poorly aerated series. This is what might be expected in a system such as that of Embden and Meyerhof in anaerobiosis.

Anaerobic dehydrogenation of hexose diphosphate and glucose. An experiment carried out at $\mathrm{pH} 7 \cdot 2$ in $0.125 \mathrm{M}-\mathrm{NaHCO}_{3}$ in equilibrium with a $5 \% \mathrm{CO}_{2}-95 \%$ $\mathbf{N}_{2}$ gas mixture gave the following $\mathbf{Q}_{\mathrm{CO}_{2}}$ values (corrected for endogenous respiration); endogenous 4.70, $0.01 \mathrm{M}$-glucose $0.03,0.01 \mathrm{M}$-hexose diphosphate 1.9 and, in presence of $0.1 \% \mathrm{~K}_{3} \mathrm{Fe}(\mathrm{CN})_{6}$ as hydrogen acceptor, glucose 35.6 , hexose diphosphate $9 \cdot 4$. The $\boldsymbol{Q}_{\mathrm{o}_{2}}$ (endogenous) was $5 \cdot 6$ and $\boldsymbol{Q}_{\mathrm{O}_{2}}$ (glucose, corrected for this endogenous value) was $4 \mathbf{1} \cdot 6$ on the same suspension.

\section{Inhibitor studies}

The effect of various inhibitors upon $\mathbf{Q}_{\mathrm{O}_{2}}$ (glucose). The respiration of washed suspensions of $\boldsymbol{S}$. griseus in phosphate buffer $\mathrm{pH} \mathrm{7.0}$ was determined in presence of various inhibitors. Table 9 shows clearly that considerable

\section{Table 9. Effect of inhibitors on $\mathbf{Q}_{\mathrm{O}_{2}}$ (glucose)}

Warburg manometers contained: main compartment, $6.9 \mathrm{mg}$. dry-wt. mycelium in $2 \mathrm{ml}$. $0.01 \mathrm{M}-\mathrm{K}$ phosphate $(\mathrm{pH} \mathrm{7.0)}$ containing inhibitor at concentration indicated; side bulb, $0 \cdot 2 \mathrm{ml}$. 0.1 м-glucose; centre well, $0 \cdot 1 \mathrm{ml}$. $10 \mathrm{~N}-\mathrm{KOH}$ with filter-paper. Temp. $28 \cdot 5^{\circ}$.

\begin{tabular}{|c|c|c|c|c|c|}
\hline \multirow[b]{2}{*}{ Expt. } & \multirow[b]{2}{*}{ Inhibitor $\mathbf{M}$} & \multicolumn{2}{|c|}{$\underbrace{Q_{\mathrm{O}_{2}}}$} & \multicolumn{2}{|c|}{$\begin{array}{l}\% \text { stimulation }(+) \text { or } \\
\text { inhibition }(-) \text { of } \\
\text { respiration }\end{array}$} \\
\hline & & Endogenous & $\begin{array}{l}\text { Corrected } \\
\text { glucose }\end{array}$ & Endogenous & $\begin{array}{l}\text { Corrected } \\
\text { glucose }\end{array}$ \\
\hline 1 & $\begin{array}{l}0 \\
2: \text { 4-dinitrophenol, } \\
0 \cdot 001\end{array}$ & $\begin{array}{r}8 \cdot 7 \\
16 \cdot 1\end{array}$ & $\begin{array}{l}18 \cdot 3 \\
26 \cdot 3\end{array}$ & $\begin{array}{r}0 \\
+85\end{array}$ & $\begin{array}{r}0 \\
+6\end{array}$ \\
\hline & $\begin{array}{l}\mathrm{NaN}_{3}, 0.001 \\
\mathrm{Na} \text { iodoacetate, } 0.001 \\
\mathrm{Na} \text { arsenite, } 0.01\end{array}$ & $\begin{array}{r}10 \cdot 4 \\
13 \cdot 8 \\
5 \cdot 8\end{array}$ & $\begin{array}{r}22 \cdot 8 \\
16 \cdot 4 \\
9 \cdot 9\end{array}$ & $\begin{array}{l}+20 \\
+59 \\
-33\end{array}$ & $\begin{array}{l}+29 \\
-73 \\
-57\end{array}$ \\
\hline 2 & $\begin{array}{l}0 \\
2: \text { 4-dinitrophenol, } \\
0.001\end{array}$ & $\begin{array}{l}10 \cdot 9 \\
19 \cdot 1\end{array}$ & $\begin{array}{l}23 \cdot 8 \\
31 \cdot 2\end{array}$ & $\begin{array}{r}0 \\
+75\end{array}$ & $\begin{array}{r}0 \\
-6\end{array}$ \\
\hline & $\begin{array}{l}\mathrm{NaN}_{3}, 0.001 \\
\mathrm{NaF}, 0 \cdot 004 \\
\mathrm{Na} \text { arsenate, } 0.01\end{array}$ & $\begin{array}{r}10 \cdot 3 \\
9 \cdot 3 \\
9 \cdot 7\end{array}$ & $\begin{array}{l}23 \cdot 9 \\
21 \cdot 7 \\
26 \cdot 8\end{array}$ & $\begin{array}{l}-6 \\
-15 \\
-11\end{array}$ & $\begin{array}{l}+6 \\
-3 \\
+33\end{array}$ \\
\hline 3 & $\begin{array}{l}0 \\
\mathrm{Na} \text { iodoacetate, } 0.001 \\
\mathrm{Na} \text { arsenite, } 0.01\end{array}$ & $\begin{array}{r}10 \cdot 1 \\
12 \cdot 0 \\
3 \cdot 0\end{array}$ & $\begin{array}{r}20 \cdot 6 \\
18 \cdot 4 \\
6 \cdot 5\end{array}$ & $\begin{array}{r}0 \\
+19 \\
-70\end{array}$ & $\begin{array}{r}0 \\
-39 \\
-67\end{array}$ \\
\hline
\end{tabular}

inhibition was caused by $0.001 \mathrm{M}$-sodium iodoacetate and by $0.01 \mathrm{M}$-sodium arsenite. Iodoacetate, however, appeared to increase endogenous respiration. 2 : 4-Dinitrophenol increased endogenous respiration. Azide (0.001 M) had little or no stimulatory effect. Arsenate, however, gave considerable stimula- 
tion of respiration, as might be expected by analogy with recorded instances of glycolysis in yeast. Preliminary experiments indicated that anaerobic $\mathrm{CO}_{2}$ production from glucose or hexose diphosphate was stimulated by arsenate.
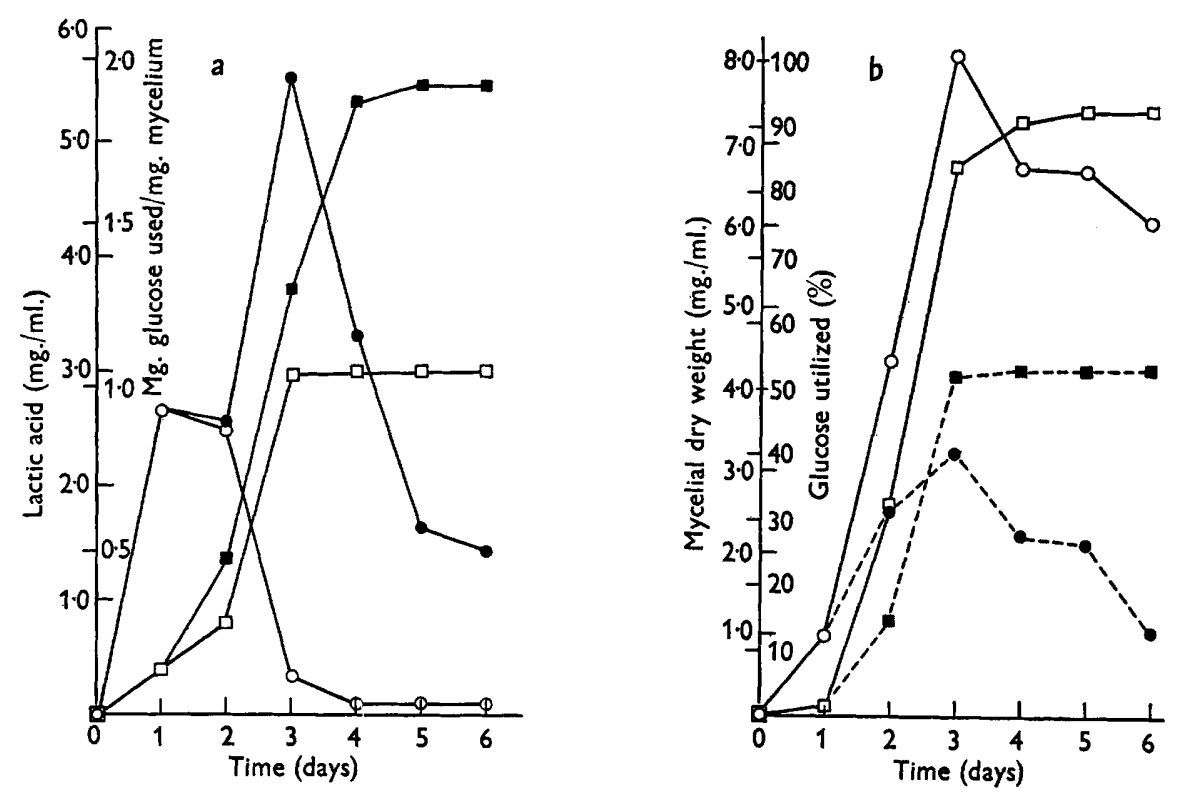

Fig. 3. Utilization of glucose and production of lactic acid in Lumb's medium. Mycelium grown aerobically for $24 \mathrm{hr}$. in shaken culture at $28.5^{\circ}$ using $40 \mathrm{ml}$. Lumb's synthetic medium $/ 250 \mathrm{ml}$. flask. At $\mathbf{2 4} \mathrm{hr}$. half of flasks capped to exclude oxygen. At intervals flasks removed in triplicate for analysis. $a,-\infty$, lactate anaerobic; $0-0$, lactate aerobic; $\square \mathrm{mg}$. of glucose utilized/mg. dry wt. of mycelium, anaerobic; $\square-\square, \mathrm{mg}$. of glucose utilized/mg. dry wt. of mycelium, aerobic. $b$, - - - mycelial dry wt., anaerobic, $\mathrm{O}-\mathrm{O}$, mycelial dry wt., aerobic; $\mathbf{\square -}$, percentage total glucose utilized, anaerobic; $\square-\square$, percentage total glucose utilized, aerobic.

The effect of various inhibitors upon growing cultures. Iodoacetate at concentrations from $10^{-4} \mathrm{M}$ to $5 \times 10^{-2} \mathrm{M}$ had no discernible effect on growth or streptomycin production on soybean media. A similar experiment showed that $2 \times 10^{-5} \mathrm{M}$ to $10^{-2} \mathrm{M}$-sodium fluoride had no detectable effect on growth or streptomycin titre.

Sodium arsenate, which had already been shown to increase the rate of oxygen uptake in presence of glucose, was also found (Table 10) to decrease the streptomycin titre without any apparent effect upon growth. (The latter could only be estimated very roughly owing to the high solids content of the medium.) However, arsenate added early in the fermentation had a secondary effect in bringing about acid $\mathrm{pH}$ conditions which may also have contributed towards decreasing the yield of streptomycin.

\section{Metabolism of acids related to the tricarboxylic acid cycle}

Oxygen uptake in presence of organic acids. Suspensions of washed, starved mycelium were tested with a number of substrates at various $\mathrm{pH}$ values

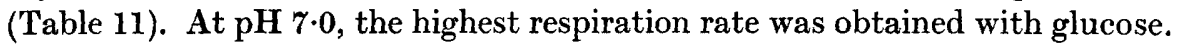


Table 10. Effect of phosphate or arsenate on streptomycin yield

Fermentations of soybean medium $(40 \mathrm{ml} . / 250 \mathrm{ml}$. shaken flask) carried out according to Dulaney (1951, Expt. 1) at $28 \cdot 5^{\circ}$. Seitz-filtered arsenate or phosphate adjusted to $\mathrm{pH} \mathrm{7 \cdot 0}$ was added to give the strength quoted in the table at the time indicated. Flasks were withdrawn in triplicate for $\mathrm{pH}$ determination and streptomycin assay (Boxer, Jelinek \& Leghorn, 1947).

\begin{tabular}{|c|c|c|c|c|c|c|}
\hline \multirow{2}{*}{$\begin{array}{c}\text { Expt. } \\
1\end{array}$} & \multirow{2}{*}{$\begin{array}{c}\text { Addition } \\
\text { Water (control) }\end{array}$} & \multirow[b]{2}{*}{$\begin{array}{l}\text { Time of } \\
\text { addition } \\
\text { (day) }\end{array}$} & Day 6 & Day 7 & Day 6 & Day 7 \\
\hline & & & \multicolumn{2}{|c|}{$\underbrace{\text { Streptomycin titre }}_{(\mu \mathrm{g} . / \mathrm{ml} .)}$} & \multicolumn{2}{|c|}{ pH value } \\
\hline 1 & Water (control) & - & $\begin{array}{l}- \\
- \\
-\end{array}$ & $\begin{array}{l}1350 \\
1180 \\
1310\end{array}$ & - & $\begin{array}{l}7 \cdot 10 \\
7 \cdot 62 \\
7 \cdot 44\end{array}$ \\
\hline 1 & K phosphate, $0.015 \mathrm{M}$ & $\mathbf{0}$ & $\begin{array}{l}- \\
- \\
-\end{array}$ & $\begin{array}{l}580 \\
510 \\
420\end{array}$ & E & $\begin{array}{l}8 \cdot 08 \\
8 \cdot 08 \\
8 \cdot 06\end{array}$ \\
\hline 2 & Water (control) & - & $\begin{array}{l}1110 \\
1280 \\
1360\end{array}$ & $\begin{array}{r}1120 \\
1020 \\
980\end{array}$ & $\begin{array}{l}7 \cdot 98 \\
7 \cdot 94 \\
7 \cdot 82\end{array}$ & $\begin{array}{l}8 \cdot 28 \\
8 \cdot 26 \\
8 \cdot 28\end{array}$ \\
\hline 2 & $\mathrm{Na}$ arsenate, $0.003 \mathrm{M}$ & 4 & $\begin{array}{l}680 \\
770 \\
750\end{array}$ & $\begin{array}{l}645 \\
640 \\
595\end{array}$ & $\begin{array}{l}7 \cdot 76 \\
7 \cdot 70 \\
7 \cdot 62\end{array}$ & $\begin{array}{l}7 \cdot 22 \\
7 \cdot 62 \\
7 \cdot 48\end{array}$ \\
\hline 2 & $\mathrm{Na}$ arsenate, $0.003 \mathrm{M}$ & 3 & $\begin{array}{l}350 \\
250 \\
330\end{array}$ & $\begin{array}{l}310 \\
290 \\
330\end{array}$ & $\begin{array}{l}7 \cdot 58 \\
7 \cdot 68 \\
7 \cdot 78\end{array}$ & $\begin{array}{l}8 \cdot 24 \\
8 \cdot 38 \\
8 \cdot 10\end{array}$ \\
\hline 2 & $\mathrm{Na}$ arsenate, $0.003 \mathrm{M}$ & 2 & $\begin{array}{l}15 \\
15 \\
10\end{array}$ & $\begin{array}{l}10 \\
15 \\
10\end{array}$ & $\begin{array}{l}5 \cdot 82 \\
5 \cdot 80 \\
5 \cdot 74\end{array}$ & $\begin{array}{l}5 \cdot 88 \\
5 \cdot 86 \\
5 \cdot 88\end{array}$ \\
\hline
\end{tabular}

Table 11. $Q_{\mathrm{O}_{2}}$ values at various hydrogen-ion concentrations for substances related to the tricarboxylic acid cycle

Warburg manometers contained: main compartment, $2.0 \mathrm{ml}$. washed starved $48 \mathrm{hr}$. mycelium in $0.1 \mathrm{M}-\mathrm{K}$ phosphate at appropriate $\mathrm{pH}$; side bulb, $0.2 \mathrm{ml}$. $0.1 \mathrm{M}$ substrate adjusted to same $\mathrm{pH}$; centre well, $10 \mathrm{~N}-\mathrm{KOH}$ on filter-paper. Temp. $28.5^{\circ}$. The $Q_{\mathrm{O}_{2}}$ (substrate) values have been corrected for $Q_{\mathrm{O}_{2}}$ (endogenous).

\begin{tabular}{|c|c|c|c|c|c|c|c|c|}
\hline \multirow[b]{3}{*}{ Substrate } & \multirow[b]{3}{*}{ Expt. } & \multirow{3}{*}{$\begin{array}{l}\text { mg. dry- } \\
\text { wt. mycelium/ } \\
\text { Warburg flask }\end{array}$} & \multicolumn{6}{|c|}{$\boldsymbol{Q}_{\mathrm{O}_{2}}$} \\
\hline & & & \multicolumn{2}{|c|}{ pH 5.0 0 - 1} & \multicolumn{2}{|c|}{$\mathrm{pH} 7 \cdot 0 \pm 0 \cdot 1$} & \multicolumn{2}{|c|}{$\mathrm{pH} 8 \cdot 0 \pm 0 \cdot 1$} \\
\hline & & & $\begin{array}{l}\text { Endo- } \\
\text { genous }\end{array}$ & $\begin{array}{l}\text { Sub- } \\
\text { strate }\end{array}$ & $\begin{array}{l}\text { Endo- } \\
\text { genous }\end{array}$ & $\begin{array}{l}\text { Sub- } \\
\text { strate }\end{array}$ & $\begin{array}{l}\text { Endo- } \\
\text { genous }\end{array}$ & $\begin{array}{l}\text { Sub- } \\
\text { strate }\end{array}$ \\
\hline Glucose & 1 & $5 \cdot 6$ & $6 \cdot 1$ & $3 \cdot 55$ & $13 \cdot 6$ & 17.7 & $16 \cdot 1$ & $17 \cdot 3$ \\
\hline Lactate & 2 & $6 \cdot 5$ & $5 \cdot 9$ & $11 \cdot 6$ & $6 \cdot 6$ & $7 \cdot 9$ & $9 \cdot 4$ & $2 \cdot 3$ \\
\hline Pyruvate & 3 & $4 \cdot 9$ & $4 \cdot 4$ & $10 \cdot 9$ & $8 \cdot 3$ & $12 \cdot 2$ & $11 \cdot 7$ & $8 \cdot 6$ \\
\hline Acetate & 3 & $4 \cdot 9$ & $4 \cdot 4$ & $4 \cdot 4$ & $8 \cdot 3$ & $10 \cdot 6$ & $11 \cdot 7$ & $9 \cdot 0$ \\
\hline Citrate & 4 & $4 \cdot 7$ & $7 \cdot 2$ & $0 \cdot 35$ & $15 \cdot 7$ & $2 \cdot 2$ & $14 \cdot 1$ & $1 \cdot 5$ \\
\hline Glutamate & 4 & $4 \cdot 7$ & $7 \cdot 2$ & $7 \cdot 0$ & $15 \cdot 7$ & $8 \cdot 0$ & $14 \cdot 1$ & $5 \cdot 2$ \\
\hline$\alpha$-Ketoglutarate & 5 & $6 \cdot 0$ & $3 \cdot 6$ & $5 \cdot 1$ & $9 \cdot 4$ & $4 \cdot 6$ & $10 \cdot 4$ & $2 \cdot 8$ \\
\hline Succinate & 6 & $8 \cdot 2$ & $4 \cdot 2$ & $5 \cdot 3$ & $10 \cdot 4$ & $9 \cdot 2$ & $10 \cdot 6$ & $4 \cdot 9$ \\
\hline Fumarate & 7 & $7 \cdot 1$ & $8 \cdot 6$ & $4 \cdot 8$ & $10 \cdot 1$ & $12 \cdot 3$ & $12 \cdot 3$ & 10.5 \\
\hline Malate & 8 & $8 \cdot 2$ & $5 \cdot 1$ & $6 \cdot 2$ & $9 \cdot 3$ & $7 \cdot 3$ & $11 \cdot 7$ & $5 \cdot 8$ \\
\hline
\end{tabular}


Fumarate, pyruvate, acetate, succinate, lactate, glutamate and malate were utilized fairly readily, but $\alpha$-ketoglutarate and citrate gave only a small increase in oxygen consumption. Lowering the $\mathrm{pH}$ to $5 \cdot 0$ decreased most $\boldsymbol{Q}_{\mathbf{O}_{2}}$ values (glucose, acetate, citrate, succinate and fumarate), those of pyruvate, $\alpha$-ketoglutarate and malate remained substantially the same, and that of lactate rose by about $40 \%$. Raising the $\mathrm{pH}$ to 8.0 led to a severe fall in $Q_{\mathrm{O}_{2}}$ values for lactate and a moderate fall for pyruvate, citrate, $\alpha$-ketoglutarate, glutamate, succinate and malate, those of glucose, acetate and fumarate remaining substantially the same.

Production of keto-acids in S. griseus cultures. Our colleagues, Dr M. McGonagle and Miss P. Dayton, drew our attention to the presence of ketoacids in certain growing cultures, and it was confirmed that young $(20-30 \mathrm{hr}$.) cultures contained considerable amounts of keto-acids.

\section{Table 12. Keto-acid derivatives from $\mathbf{S}$. griseus cultures}

All chromatograms carried out on Whatman no. 4 paper by ascending flow. About $10 \mu \mathrm{g}$. total derivative used. Distance moved by the solvent front about $25 \mathrm{~cm}$.

\begin{tabular}{|c|c|c|c|}
\hline \multirow{3}{*}{$\begin{array}{l}\text { Material examined } \\
\text { Authentic }\end{array}$} & \multicolumn{3}{|c|}{$\begin{array}{c}100 \times R_{\mathrm{F}} \text { values of } 2: 4 \text {-dinitrophenyl- } \\
\text { hydrazones }\end{array}$} \\
\hline & $\begin{array}{l}1 \% \\
\mathrm{Na}_{2} \mathrm{CO}_{3} \\
(2 \mathrm{hr})\end{array}$ & $\begin{array}{c}\text { sec-butanol } / 4 \% \\
(v / v) \text { aqueous } \\
0 \cdot 880 \text { sp.gr. } \\
\text { ammonia }(80: 20) \\
(17 \mathrm{hr} .)\end{array}$ & $\begin{array}{c}n \text {-hexanol satd. } \\
\text { with } 4 \% \mathrm{v} / \mathrm{v} \\
\text { aqueous } 0 \cdot 880 \mathrm{sp} . \mathrm{gr} . \\
\text { ammonia } \\
(17 \mathrm{hr} .)\end{array}$ \\
\hline & & & \\
\hline Dimethyl pyruvic & 60 & $>95$ & 65 \\
\hline$\alpha$-Ketobutyric & 42 & $>95$ & 48 \\
\hline Pyruvic & 59,42 & 85,76 & 14,33 \\
\hline Glyoxalic & 57 & 49 & - \\
\hline Oxaloacetic & 80 & 15 & $\mathbf{0}$ \\
\hline$\alpha$-Ketoglutaric & 62 & 9 & $\mathbf{0}$ \\
\hline $\begin{array}{l}\text { Keto-acids in } 24 \mathrm{hr} \text {. culture in } \\
\text { meat medium }\end{array}$ & $\begin{array}{l}\mathbf{7 2} \\
\mathbf{5 7}\end{array}$ & $\begin{array}{r}>95 \\
86 \\
15 \text { (trace) } \\
8 \text { (trace) }\end{array}$ & $\begin{array}{l}89 \\
66 \\
14\end{array}$ \\
\hline $\begin{array}{l}\text { Keto-acids in } 24 \mathrm{hr} \text {. culture in } \\
\text { Lumb's medium }\end{array}$ & $\mathbf{5 7}$ & 74 & 12 \\
\hline Keto-acids formed on incubating & 57 & 8 & 14 \\
\hline washed, starved mycelium with & 62 & 15 (trace) & 66 (trace) \\
\hline $\mathbf{K}$ fumarate & 77 (trace) & 77 & 89 (trace) \\
\hline $\begin{array}{l}\text { Keto-acids formed on incubating } \\
\text { washed, starved mycelium with } \\
\text { K lactate }\end{array}$ & 57 & 74 & 15 \\
\hline $\begin{array}{l}\text { Keto-acids formed on incubating } \\
\text { washed, starved mycelium with } \\
\text { K malate }\end{array}$ & $\begin{array}{l}56 \\
65 \text { (trace) }\end{array}$ & $\begin{array}{l}77 \\
8 \text { (trace) }\end{array}$ & 13 \\
\hline
\end{tabular}

Inoculum development (meat) medium cultures, as described by Dulaney (1951), contained $0.38 \mathrm{mg}$. keto-acid/ml. at $24 \mathrm{hr}$. This was found to be principally 'pyruvate' as estimated by the method of Friedemann \& Haugen (1943), and paper chromatography revealed that about $90 \%$ was pyruvate. There appeared also to be traces of $\alpha$-ketoglutarate and oxaloacetate, as well 
as two substances giving faster-moving 2:4-dinitrophenylhydrazones (Table 13). The pyruvate derivative was purified by passage through an alumina column and recrystallized, m.p. 217-218.5 (authentic compound m.p. 217-217.5 ${ }^{\circ}$; mixed m.p. 217-218.5 $5^{\circ}$ uncorr.). From another portion of the same culture fluid was prepared 3-methylnitroquinoxalin-(2)-ol, m.p. 246-249 ${ }^{\circ}$ (authentic compound m.p. 247-248 ${ }^{\circ}$; mixed m.p. 246-249 ${ }^{\circ}$ uncorr.).

Lumb's medium at $24 \mathrm{hr}$. contained $0 \cdot 198 \mathrm{mg}$. keto-acid $/ \mathrm{ml} .(0 \cdot 162 \mathrm{mg}$. apparent pyruvate/ml.; Table 12). The 2:4-dinitrophenylhydrazone of pyruvate was isolated, m.p. 217-218 ${ }^{\circ}$ (authentic compound, m.p. 217-217.5 ${ }^{\circ}$; mixed m.p. $217^{\circ}$ uncorr.). The keto-acid content of a $24 \mathrm{hr}$. culture in soybean medium resembled that of meat medium. Again pyruvate was the predominant component and its 2:4-dinitrophenylhydrazone was isolated,

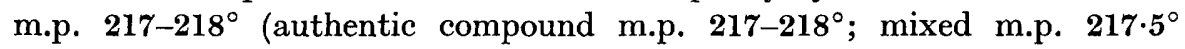
uncorr.).

Keto-acid production from organic acids. Washed mycelial suspensions were incubated with various substrates in presence or absence of $0.02 \mathrm{M}$-sodium arsenite. All experiments were carried out in $0.005 \mathrm{M}$-potassium phosphate

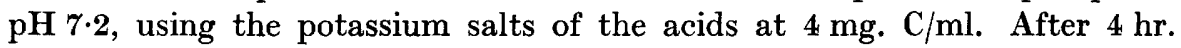
shaking in air at $28 \cdot 5^{\circ}$, the flasks were tested for keto-acid production (Table 13 ). Much higher yields were obtained in the presence of arsenite than in its absence.

\section{Table 13. Production of keto acids from organic acids and glucose}

$250 \mathrm{ml}$. flasks contained $40 \mathrm{ml}$. of the following mixture: glucose or K salts of organic acids at a concentration equivalent to $4 \mathrm{mg}$. carbon $/ \mathrm{ml}$. in $0.005 \mathrm{M}-\mathrm{K}$ phosphate $\mathrm{pH} 7 \cdot 2$ containing $0.01 \mathrm{~m}-\mathrm{Na}$ arsenite and about $140 \mathrm{mg}$. dry-wt. of washed, starved $S$. griseus. The flasks were shaken for $4 \mathrm{hr}$. at $25^{\circ}$; gas phase, air. Bracketed figures represent ketoacid titre in absence of arsenite.

\begin{tabular}{|c|c|c|c|}
\hline & $\begin{array}{l}\text { Total keto-acids } \\
(\mathrm{mg} \cdot / \mathrm{ml} .)\end{array}$ & $\begin{array}{l}\text { 'Pyruvate' } \\
\text { (mg./ml.) }\end{array}$ & $\begin{array}{c}\text { 'Ketoglutarate" } \\
\text { (mg./ml.) }\end{array}$ \\
\hline Glucose & $4.50(0.07)$ & $4.45(0.02)$ & $0.05(0.05)$ \\
\hline Acetate & $2 \cdot 32(0 \cdot 10)$ & $2 \cdot 32(0 \cdot 00)$ & $0.00(0 \cdot 10)$ \\
\hline Lactate & $2.49(0.00)$ & $2.49(0.00)$ & $0.00(0.00)$ \\
\hline Glutamate & 0.07 & 0.00 & $0 \cdot 07$ \\
\hline Citrate & 0.03 & 0.02 & 0.01 \\
\hline Succinate & $1 \cdot 08$ & $1 \cdot 12$ & 0.00 \\
\hline Fumarate & $22.9 \quad(1 \cdot 22)$ & $14.3 \quad(0.04)$ & $8 \cdot 6 \quad(0.82)$ \\
\hline Malate & $13.9 \quad(0.58)$ & $12.9 \quad(0.23)$ & $1.0 \quad(0.35)$ \\
\hline Control & 0.04 & 0.02 & 0.00 \\
\hline
\end{tabular}

Similar experiments carried out at $\mathrm{pH} 5.0$ and 8.5 without arsenite, or at $\mathrm{pH} 7 \cdot 2$ with $10^{-3} \mathrm{M}-2$ : 4-dinitrophenol gave very much lower yields. Pyruvate was the principal keto-acid formed in all cases, the proportion of $\alpha$-ketoglutaric acid being very small except from fumarate.

The experiment with fumarate was repeated on a larger scale to give a total reaction volume of $320 \mathrm{ml}$. containing finally about $6.6 \mathrm{mg}$. keto-acid $/ \mathrm{ml}$. (mainly 'pyruvate'). Paper chromatography of the 2:4-dinitrophenylhydrazones revealed that pyruvate in both tautomeric forms accounted for most of the keto-acids, but that some $\alpha$-ketoglutarate and a trace of oxaloacetate were also present (Table 12). The $2: 4$-dinitrophenylhydrazine deriva- 
tive, isolated from $160 \mathrm{ml}$. of the reaction mixture on an alumina column, was washed with hot benzene and recrystallized from hot nitrobenzene, m.p. 208-208.5 ${ }^{\circ}$. Analysis gave $\mathrm{C}, 40 \cdot 68 ; \mathrm{H}, 2.98 ; \mathrm{N}, \mathbf{2 0} \cdot 8 \%$-as against $\mathrm{C}, 40 \cdot 15$; $\mathrm{H}, 3 \cdot 30 ; \mathrm{N}, \mathbf{2 0} \cdot \mathbf{8 0} \%$-for authentic pyruvic acid $2: 4$-dinitrophenylhydrazone. From a similar $160 \mathrm{ml}$. of reaction mixture, the nitroquinoxalinols were prepared and isolated. The product was almost all the pyruvate derivative, 3-methyl-nitroquinoxalin-(2)-ol, m.p. 248-248.5 ${ }^{\circ}$ (authentic sample m.p. 247-248 ${ }^{\circ}$; mixed m.p. 247-248 ${ }^{\circ}$ uncorr.).

It is therefore certain that pyruvate was the principal ketonic product obtained from fumarate or malate. It must be remembered, however, that much of any oxaloacetate originally formed might have been decarboxylated to give this acid under the conditions of isolation. Similar experiments carried out over $24 \mathrm{hr}$. gave similar yields of keto-acid from lactate or malate; this also was almost wholly pyruvate.

\section{Other constituents of mycelium detected}

Mycelium from fermentations of soybean medium or of Lumb's medium was spun down, washed, and hot-water extracts made which were examined for hydroxy and polybasic organic acids. The only carboxylic acid detected in appreciable amount was glutamic acid. Other chromatograms showed that the whole range of amino acids was probably present in addition to glutamic acid, of which about $0.1 \mathrm{mg} . / \mathrm{ml}$, was present in the whole culture. The following amino acids were identified at about one-fifth this concentration: alanine, glycine (in the soybean medium; it was present from the start in Lumb's medium), arginine and aspartic acid. About eight other amino acid spots were separable, but were not identified. Apart from glycine in Lumb's medium, which fell to about $0.1 \mathrm{mg} . / \mathrm{ml}$., the levels of amino acids remained substantially the same after day 3. It is likely that all amino acids necessarily needed by the organism for its growth can be synthesized.

\section{DISCUSSION}

In normal aerobic cultures the principal final products of glucose metabolism are mycelium and $\mathrm{CO}_{2}$. Under conditions of restricted aeration some accumulation of lactic acid occurs. The results reported do not clearly differentiate between breakdown by way of the classical Embden-Meyerhof scheme or by some alternative mechanism such as the hexose monophosphate shunt (Lipmann, 1936; Dickens, 1938; Koepsell, 1950; Scott \& Cohen, 1951). It should, however, be noted that work upon the related organisms Streptomyces scabies and $S$. coelicolor (Cochrane, Peck \& Harrison, 1953) indicated that the hexose monophosphate shunt is almost certainly the means by which glucose is broken down by these organisms. Although the terminal metabolism cannot be proven to take place by way of a tricarboxylic acid cycle, nothing has been found to support the claims of Garner \& Koffler (1951) that it is not operative in $S$. griseus. The failure to metabolize acids of the cycle without prior adaptation, upon which their conclusions are based, may have been due to failure to absorb these acids through the cell wall. 
Streptomycin synthesis, the putting together of sugar-like residues, behaved towards arsenate or phosphate (see Perlman \& Wagman, 1952) as might be predicted from the behaviour of similar polymerizations (e.g. synthesis of starch from glucose-1-phosphate). This behaviour implies the existence of phosphorylated intermediates. These, however, were not present in detectable amounts.

We wish to thank Mrs D. Goodinson for technical assistance.

\section{REFERENCES}

Bandurski, R. S. \& Axelrod, B. (1951). The chromatographic identification of some biologically important phosphate esters. J. biol. Chem. 193, 405.

Boxer, G. E., Jelinek, V. C. \& Leghorn, P. M. (1947). The colorimetric determination of streptomycin in clinical preparations, urine and broth. J. biol. Chem. $169,153$.

Bryson, J. L. \& Mrtchell, T. J. (1951). Improved spraying reagents for the detection of sugars on paper chromatograms. Nature, Lond. 167, 864.

Cavallini, D., Frontali, N. \& Toschi, G. (1949). Determination of keto-acids by partition chromatography on filter-paper. Nature, Lond. 163, 568.

Chesters, C. G. C. \& Rolinson, G. N. (1951). Trace elements and streptomycin production. J. gen. Microbiol. 5, 559.

Cochrane, V. W. \& Peck, H. D., Harrison, A. (1953). Metabolism of Streptomyces species. VII. Hexose monophosphate shunt and associated reactions. J. Bact. 66, 17.

Conn, J. E. (1943). The pigment production of Actinomyces coelicolor and A. violacensruber. J. Bact. 46, 133.

Datta, S. P., Harris, H. \& Rees, K. R. (1950). Chromatography of 2 : 4-dinitrophenylhydrazones of ketoacids on alumina. Biochem. J. 46, xxxvi.

Dickens, F. (1938). Oxidation of phosphohexonate and pentose phosphoric acids by yeast enzymes. Biochem. J. 32, 1926.

Dulaney, E. L. (1949). Observations of Streptomyces griseus. III. Carbon sources for growth and streptomycin production. Mycologia, 41, 1.

Dulaney, E. L. (1951). Production of streptomycin from an improved strain of Streptomyces griseus. U.S. Pat. 2,571,693. (Merck and Co. Inc.)

Dulaney, E. L., Hodges, A. B. \& Perlman, D. (1947). Physiological studies on Actinomyces griseus. J. Bact. 54, 1.

Dulaney, E. L. \& Perlman, D. (1947). Observations on Streptomyces griseus. I. Chemical changes occurring during submerged streptomycin fermentation. Bull. Torrey bot. Cl. 74, 504.

Elson, L. A. \& Morgan, W. T. J. (1933). A colorimetric method for the determination of glucosamine and chondrosamine. Biochem. J. 27, 1824.

Fiske, C. H. \& SubBarow, Y. (1925). The colorimetric determination of phosphorus. J. biol. Chem. 66, 375.

Friedemann, T. E. \& Haugen, G. E. (1943). Pyruvic acid. II. The determination of keto-acids in blood and urine. J. biol. Chem. 147, 415.

Garner, H. R. \& Koffler, H. (1951). Preliminary evidence against the existence of a Krebs cycle in Streptomyces griseus. Bact. proc. 139.

Gordon, J. J. \& QuASTEL, J. H. (1939). Estimation of lactic acid in biological material by oxidation with ceric sulphate. Biochem. $J .33,1332$.

Gottlieb, D. \& Anderson, H. W. (1948). The respiration of Streptomyces griseus. Science, 107, 172.

HockenHuld, D. J. D. (1953). A new spraying agent for paper chromatography of carbohydrates and polyols. Nature, Lond. 171, 982. 
Hockenhull, D. J. D. \& Floodgate, G. D. (1952). o-Phenylenediamine and 1 : 2-diamino-4-nitrobenzene as reagents for $\alpha$-keto acids. Biochem. J. 52, 38.

Hockenhule, D. J. D., Hunter, G. D. \& Herbert, M. W. (1953). Separation of derivatives of $\alpha$-keto acids by paper chromatography. Chem. \& Ind. (Rev.) p. 127.

Hockenhuld, D. J. D., Herbert, M., Walker, A. D., Wilkin, G. D. \& Winder, F. D. (1954). Organic acid metabolism of Penicillium chrysogenum. I. Lactate and acetate. Biochem. J. 56, 73.

Hockenhull, D. J. D., Walker, A. D., Wilkin, G. D. \& Winder, F. G. (1952). Oxidation of phenylacetic acid by Penicillium chrysogenum. Biochem. J. 50, 605.

Jeanes, A., Wise, C. S. \& Dimler, R. J. (1951). Improved techniques in paper chromatography of carbohydrates. Anal. Chem. 23, 415.

Koepseld, H. J. (1950). Gluconate oxidation by Pseudomonas fluorescens. J. biol. Chem. 186, 743.

Lipmand, F. (1936). Fermentation of phosphogluconic acid. Nature, Lond. 138, 588.

Lugg, J. W. H. \& Overell, B. T. (1947). Partition chromatography of organic acids on a paper sheet support. Nature, Lond. 160, 87.

Neuberg, C. \& Kobel, M. (1933). Behaviour of glyceric acid monophosphate in the presence of yeast. II. Biochem. Z. 263, 219.

Partridge, S. M. (1948). Filter-paper partition chromatography of sugars. Biochem. J. 42, 238.

Partridge, S. M. (1949). Aniline hydrogen phthalate as a spraying reagent for chromatography of sugars. Nature, Lond. 164, 443.

Perlman, D. \& Wagman, G. H. (1952). Studies on the utilisation of lipids by Streptomyces griseus. J. Bact. 63, 253.

Pridham, T. G. \& GotTlieb, D. (1948). The utilisation of carbon compounds by some actinomycetales as an aid for species determination. J. Bact. 56, 107.

RoE, J. H. (1934). A colorimetric method for the determination of fructose in blood and urine. J. biol. Chem. 107, 15.

Saro, S. (1921). (Carbohydrate constituents of soya beans.) Tohoku Imp. Univ. Tech. Reps. (Japan). From Markley, K. S. \& Goss, W. H. (1944). Soybean Chemistry and Technology. Brooklyn: Chemical Pub. Co. Inc.

Scevola, M. E. \& Valcurone, G. (1952). Prodotti intermedi del metabolismo glucido dello $S$. griseus. Farmaco, 7, 622.

ScotT, D. B. M. \& CoHen, S. S. (1951). Enzymatic formation of pentose phosphate from 6-phosphogluconate. J. biol. Chem. 188, 509.

Somogyi, M. (1937). A reagent for the copper-iodometric determination of very small amounts of sugar. J. biol. Chem. 117, 771.

Stark, J. B., Goodban, A. E. \& Owens, H. S. (1951). Paper chromatography of organic acids. Anal. Chem. $23,413$.

Street, J. P. \& Bailey, E. M. (1915). Carbohydrate constituents of soya beans. Industr. Engng Chem. 7, 853.

Trevelyan, W. E., Forrest, R. S. \& Harrison, J. S. (1952). Determination of yeast carbohydrates with the anthrone reagent. Nature, Lond. 170, 626.

Vercellone, A. \& Neuberg, C. (1935). Further simplification of the method for the preparation of $\mathrm{D}(-)$ 3-phosphoglyceric acid. Biochem. Z. 280, 161.

Waksman, S. A. (1950). Annales Cryptogamica and Phytopathologica, chap. v, The Actinomycetes. Waltham, Mass: Chronica Botanica Co.

Whistler, R. L. \& Durso, D. F. (1950). Chromatographic separation of sugars on charcoal. J. Amer. Chem. Soc. 72, 677.

WoodrufF, H. B. \& Ruger, M. (1948). Studies on the physiology of a streptomycinproducing strain of Streptomyces griseus on proline medium. J. Bact. 56, 315. 